\title{
The E-Filing Tax Implementation Success Examined From The Taxpayer Agency as User
}

\author{
Windriati*, M. Husni Thamrin \& Nurmah Semil \\ Public Administration Study Program, Faculty of Social and Political Sciences, \\ Universitas Sriwijaya, Indonesia
}

Received: 28 January 2021; Reviewed: 13 March 2021; Accepted: 24 April 2021

*Coresponding Email: windriati22@gmail.com

\begin{abstract}
This study aimed at analyzing the effect of system quality, information quality, and service quality to the implementation of e-Filing tax system on net benefits with user satisfaction as an intervening variable at the Pratama Palembang Ilir Barat Tax Service Office (TSO). This research was a quantitative study with survey approach through distributing questionnaires to 350 respondents as samples. To analyze the data, Covariance Base Structure Equation Modeling (CB-SEM) was used. The results indicated that the quality of systems, information and service positively and significantly affected the user satisfaction with the percentage of $16 \%, 20 \%$, and $26 \%$, respectively. Likewise, the e-Filing user satisfaction had a positive and significant effect on the net benefits with the percentage of $64 \%$. The results of this study recommend that, despite its being mandatory, the implementation of e-Filing system could provide satisfaction to the users. This indicated that the system is currently as expected; not only due to its being mandatory, but the users satisfaction also contributed to the system's sustainability. The output of the services provided in the form of taxpayer compliance, however, has not shown optimal results. Thus, a continuous reformation of the system, information, and service quality is hoped to be conducted.
\end{abstract}

Keywords: Implementation; E-Filing; The DeLone and McLean Information System Success Model

How to Cite: Windriati, Thamrin, M.H., \& Semil, N. (2021). The E-Filing Tax Implementation Success Examined From The Side Of The Taxpayer Agency As User. Jurnal Administrasi Publik (Public Administration Journal). 11 (1): 88-100. 


\section{INTRODUCTION}

The e-Filing policy is initiated by the Directorate General of Taxes (DGT) due to the increasing need requested by taxpayers throughout Indonesia who demand betterment in the service and the desire to simplify the administrative process from printed-paper tax reports to paperless ones. The presence of e-Filing as an information system in taxation services that has a system, information, and service quality is certainly effective if it can meet user satisfaction and can provide net benefits for taxpayers as users both personally and organizationally as well.

Based on the 2018 DGT annual report, the number of e-Filing users was $9,152,817$ taxpayers in total or grew $8.83 \%$ from 2017. Viewed from the service side, the DGT Service User Satisfaction Index was recorded at 4.32 from a range of 0.00 (not satisfied) to 5.00 (very satisfied). These two facts indicate an increase in the interest and fulfillment of taxpayers' demands for the services provided, especially for the e-Filing system. However, the ratio of the compliance level for submitting Annual Income Tax Returns was still at $71.10 \%$. The low level of compliance becomes a concern for DGT to increase awareness and service to taxpayers as a first step in enforcing compliance and collecting state revenue from the tax sector.

The importance of information systems in the implementation of tax obligations and their development which requires planning and implementation in accordance with the objectives, has led the support facilities for quality information and a systematic database as the foundation of the Third Volume Tax Reform which focuses on the five pillars of the institution, which include the organizational field, the human resources field (HR), the information technology and databases field, the business processes field, and the legislation field.
The recent Director General of Taxation Regulation Number PER02/PJ/2019 concerning Procedures for Submitting, Receiving and Processing Tax Returns reaffirms the obligation to submit SPT through e-Filing which certainly must be socialized and understood by taxpayers as service users. Therefore, the main objective of the implementation of this regulation, which can ease the administrative demands on taxpayers and help to improve the ease of doing business as well, can be conveyed properly. This is in line with DGT's target of increasing awareness which is not only concerning the taxpayer compliance in the implementation of tax obligations.

Expensive investments attempted in the adoption and information systems development do not always produce quality and go with the expected outputs and outcomes. According to (Choi et al., 2016) there are many interrelated variables influencing the successful implementation of an information system, while failure generally occurs because there is a mismatch between the system and business processes and the information needed by the organization.

To really understand the value of various management activities and information system investment, measuring the success or effectiveness of the information system is the utmost importance. (Santhanamery et al., 2019) One model that is widely used and tested in research to examine behavioral aspects in the implementation of an information system, especially implementation at the organizational level which is mandatory (mandatory), is a model developed by DeLone and McLean (2003) known as DeLone and McLean's updated Information System Success Model. (figure 1.1) 


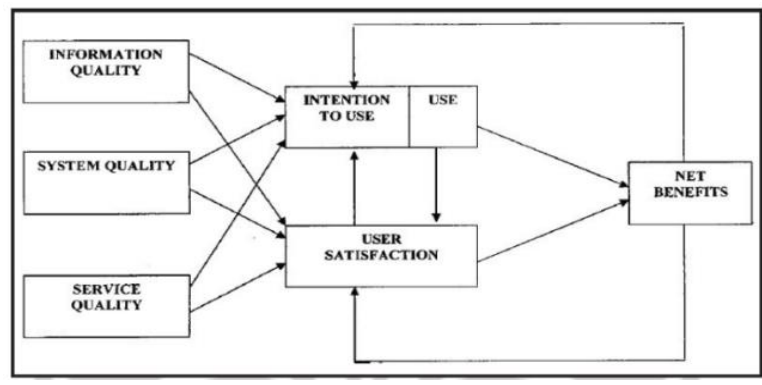

Figure 1. DeLone and McLean's updated Information Systems Success Model (2003)

One of the sources that is used as a reference and comparison in this research is previous research which is considered quite relevant to the research that will be carried out at this time, namely regarding the implementation of the e-Filing Tax system.

Santhanamery \& Ramayah (2012), conducted a study to investigate the role of optimism bias in the phenomenon of eFiling information system implementation in Malaysia. The survey was conducted on individual taxpayers who have used the eFiling system at least once in five main cities in Malaysia. This study will emphasize the risk estimation by taxpayers when involved in the e-filing system. By identifying the level of optimism bias in the e-Filing system with the results of the research showing that Malaysian taxpayers have a level of concern about the privacy and security of online personal information breaches.

Ihsan (2018), examines the evaluation of the e-Filing system that has been running based on the user's point of view of the taxpayer in Makasar Madya KPP with the Information System Success Model approach by DeLone and McLean (1992). The results of the research prove empirically that the implementation of the e-Filing system has not been successful and has not been successful because "of the nine proposed hypotheses, not all of them are proven and can be accepted. Therefore, "it is recommended that the Directorate General of Taxes" continues to strive to improve the quality of the system, strengthen and expand the application of the e-Filing system. "

Christanti (2019), examines the effect of e-government quality embodied in the Annual SPT reporting system, on user satisfaction. With the information success model developed by DeLone and McLean (2003) and combining the relationships between other constructs studied, namely the effect of user satisfaction on the conative use of information systems which is reflected by several elements including; adoption, reinvention, and learning. The results showed that the quality of the information produced had an effect on user satisfaction, while user satisfaction had an effect on the conative use of e-government. However, "system quality and service quality have no effect on user satisfaction".

This study conducted an empirical test using five of the six variables used in The updated DeLone and McLean's 2003 Model approach, which include system quality, information quality, service quality, user satisfaction, and net benefits in order to analyze the factors that will affect the successful implementation of the e-Filing tax system. The elimination of the use variable was carried out since it would help to create a less difficult measurement of the information system implementation success in a mandatory environment. Based on previous studies, the measurement of the use of mandatory systems has shown inconsistent results. In this case, e-Filing is a special system that acts as a means for taxpayers to fulfill their tax obligations.

Therefore, the measurement of use in a mandatory system cannot accurately reflect the user's reaction to the information system (Amriani, T. N., \& Iskandar, 2019). Adopting Delone and McLean's model of success 2003, the relationship between the variables tested, based on user responses, in terms of system quality variables available on the eFiling system with flexible system indicators, is considered reliable because 
the variables are integrated with other systems. The system quality seeks out to determine whether the system can be accessed properly and comfortably, can respond to instructions quickly, and use language and user-friendly commands. These capabilities of the system, if any, will greatly affect and fulfill the user satisfaction variable.

It goes all the same way with the information quality variable in e-Filing. This variable determines whether the information is presented completely, precisely, accurately and uses a current format that is easy to understand. Additionally, if the system can guarantee data security, it will certainly increase the user satisfaction variable. Another important variable is the service quality provided in the e-Filing information system. This variable is employed whether the system can meet user needs, make it easy and reliable, provide solutions to constraints, and have the support of socialization and information from DGT as a service provider. The objective of the system is to captivate the hearts of users so that it can affect and meet user satisfaction variables.

Even though it is mandatory, the eFiling system shall also meet the user satisfaction variable. The basic aims of conducting the e-Filing system conducted by DGT to taxpayers are to increase user satisfaction and to make them perceive this system is highly capable to meet their needs, to achieve efficient and satisfied objectives for the quality of the system, information, and services available. It will eventually affect the net benefit variables for individuals and organizations and increase the performance and productivity of users effectively and efficiently. To sum up, all these variables can form and be used as an assessment to determine the success of the e-Filing information system as a whole.

\section{RESEARCH METHODS}

The quantitative approach format was carried out to notice the influence between variables using the hypothesis proof which was analyzed by inferential statistics. The implementation of this eFiling tax system was conducted to comprehend the effect of system quality, information quality and service quality through user satisfaction on the net benefits of corporate taxpayers at Palembang Ilir Barat Pratama Tax Service Office.

The population in this study plan was all corporate taxpayers registered at Palembang Ilir Barat Pratama Tax Service Office with an active status as registered users of the e-Filing system based on 2019 e-Filing reporting data, totaling 2,565 business entities or companies and sample of 350 taxpayers was determined.

The type of questionnaire used in this study is a closed questionnaire. It is defined as a questionnaire that independently provides the answer. The scale used in measuring the answers to the questionnaire which were delivered to respondents is a Likert scale. This scale is able to measure attitudes, opinions, and perceptions of a person or group concerning social events or phenomena.

The options provided for the statements and distributed to the respondents are determined by ranking scores, as follows: A. Strongly agree $(\mathrm{SA})=$ score 5; B. Agree (A) = score 4; C. Mildly Agree $(\mathrm{MA})=$ score 3 ; D. Disagree $(\mathrm{D})=$ score 2; E. Strongly Disagree (SD) = score 1 .

After testing the validity and reliability of the instrument, questionnaires were distributed online via Google Form via email and an official WhatsApp account of Palembang Ilir Barat Pratama Tax Service Office. The questionnaire distribution was also manually conducted through a face-to-face meeting with corporate. The results were converted from the ordinal scale data to 
the interval one followed by data analysis techniques.

This study is an estimation research form which is used to test an empirical model with valid and reliable measures. Tests and measurements are carried out at the indicator level. The hypothesis being tested is a model hypothesis. The measurement criterion for testing the feasibility of the model is called the goodness of fit test. For having the estimation purposes of the current study, CB-SEM is the only right technique to use. Considering the assumptions and requirements for selecting the analysis model and considering the size of the sample as well, covariance-based SEM (CBSEM) was chosen as an analysis tool in this study in which the researcher also used the LISREL application as data processing support software in this study.

Based on the theoretical review, previous research as well as the conceptual framework, the hypothesis model of this study is formulated in the following Figure 2:

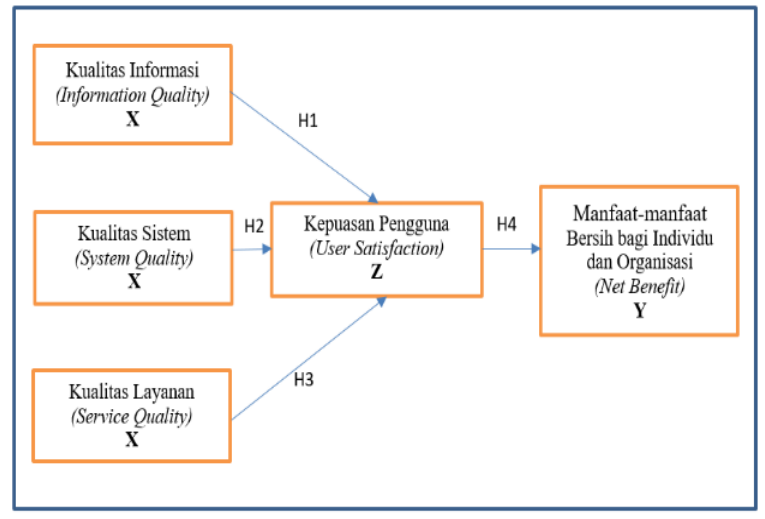

Figure 2 Conceptual Framework and Hypothesis Model

DeLone and McLean (1992 and 2003) found that system quality can affect user satisfaction. Results of several studies have supported this statement and found a strong relationship between system quality and information system user satisfaction. The studies that confirm this finding are; (Sumiyati et al., 2013; Amriani, \& Iskandar, 2019; Choi et al., 2016;
Hidayat, 2019; Bahesa, 2018; Irfan, 2019). The positive direction of influence means that the higher the quality of the system is, the higher the user satisfaction will be.

The quality of the e-Filing system that meets the flexibility, integration, ease of use, response time, the language indicators will affect user satisfaction towards the eFiling system. Based on the description above, the hypothesis of this study is proposed as follows:

H1: The quality of the information system has a positive effect on user satisfaction with the e-Filing system.

According to research conducted by DeLone and McLean (1992 and 2003), the quality of the information in a system can affect user satisfaction. Several results of studies initiated by (Wahyuni, 2011; Tjahjadi, 2014) have supported this statement and have found out that there is a strong relationship between information quality and user satisfaction.

The information quality generated by an information system can affect user satisfaction. If the quality of information produced by the e-Filing system meets the indicators of completeness, ease of understanding, relevance, security, and accuracy, it will increase e-Filing user satisfaction. Based on the description above, the hypothesis of this study is proposed as follows:

H2: The information quality has a positive effect on user satisfaction with the e-Filing system.

Define service quality as a comparison between customer expectations and the perceived service they actually receive (Wibisono \& Toly, 2014; Christanti, 2015; Mardiana et al., 2015b; Siregar, 2015; Surdin \& Ilmu, 2016). A study conducted by DeLone and McLean (2003) showed that service quality has a significant impact on user satisfaction. Additionally, the service quality factor is more important than others since the current system users are the external part of the organization which 
operates the system as a form of service provided by an organization.

If the output of the e-Filing system meets the quality indicators in the form of tangibility, reliability, responsiveness to constraints, the ability to assure and understand (empathy) the user satisfaction will be easily obtained, then. This user satisfaction will encourage the use of the e-Filing system and raise a level of awareness, not just compliance rate. Therefore the hypothesis of this study is put forward as follows:

H3: Service quality has a positive effect on user satisfaction with the e-Filing system.

The study conducted by DeLone and McLean (2003) showed that user satisfaction is a significant predictor of individual impact and organizational impact which is reflected in net benefits.
User satisfaction with the e-Filing system that can meet system indicators according to needs, overall satisfaction, usefulness, effectiveness, and efficiency will affect individual performance in the organization. If user satisfaction is high, the net benefits felt by both individuals and organizations will be higher as well. Therefore, the hypothesis of this study is put forward as follows (Mardiana et al., 2015a; Choi et al., 2016; Azwar, 2016; Puspita \& Ritchi, 2017; Muttaqin, 2020):

H4: User satisfaction of the e-Filing system has a positive effect on net benefits for individuals and organizations.

\section{RESULTS AND DISCUSSION}

The number of respondents in this study was balanced between male and female respondents, each with 175 people or 50.00 percent for each gender (Tabel 1).

Tabel 1. Sex of The Respondents

\begin{tabular}{lll}
\hline Gender & Number of Respondents (persons) & Percentage (\%) \\
\hline Male & 175 & 50,00 \\
Female & 175 & 50,00 \\
\hline Total & 350 & 100,00 \\
\hline
\end{tabular}

Source: primary data processed

Most of the respondent's ages are in 39.43 percent of respondents were in the the productive age range. The generation age range of 30-40 years and the remaining that adapts very quickly to technology is the 65 people or 18.57 percent of the 20-30 years age range, which accounts for respondents were in the age range over 40 147 people or 42.00 percent of the total years (Tabel 2). respondents. As many as 138 people or

Tabel 2. Age Range of The Respondents

\begin{tabular}{lll}
\hline Age Range (year) & Number of Respondents (persons) & Percentage (\%) \\
\hline $20-30$ & 147 & 42,00 \\
$30-40$ & 138 & 39,43 \\
$>40$ & 65 & 18,57 \\
\hline Total & 350 & 100,00 \\
\hline
\end{tabular}

Source: primary data processed

Most of the respondents obtained a bachelor's degree (S1) as many as 242 people or 69.14 percent. 24.29 percent or 85 respondents were high school/diploma graduates and 6.57 percent or as many as 23 respondents had obtained Master degrees.
This high level of formal education is expected to support respondents in utilizing the e-Filing system more effectively, efficiently, and more adaptive to changes in the use of information technology (Tabel 3). 
Tabel 3. Recent Education Degree of The Respondents

\begin{tabular}{lll}
\hline Recent Education Degree & Number of Respondents & Percentage (\%) \\
\hline High School/Diploma & 85 & 24,29 \\
Bachelor S1 & 242 & 69,14 \\
Magister/S2 & 23 & 6,57 \\
\hline Total & 350 & 100,00 \\
\hline
\end{tabular}

Source: primary data processed

Most respondents have used e-Filing adapted some updates. As many as 73 for more than 2 years, and it accounted for a people or 20.86 percent of respondents percentage of 68.86 percent or as many as used e-Filing within a span of 1-2 years and 241 people. This shows that the the remaining 36 people or 10.28 percent of respondents represent active users and the total respondents were new users of eusers who have undergone changes to the Filing which has used the system for only reporting information system and have less than a year (Tabel 4).

Tabel 4. Time Range Using E-Filing of The Respondents

\begin{tabular}{lll}
\hline Time Range Using E-Filing (Years) & Number of Respondents (persons) & Percentage (\%) \\
\hline$<1$ & 36 & 10,28 \\
$1-2$ & 73 & 20,86 \\
$>2$ & 241 & 68,86 \\
\hline Total & 350 & 100,00 \\
\hline
\end{tabular}

Source: primary data processed

The respondent's answer index for the system quality variable was 3.154 , all indicators were categorized as sufficient with the highest value in the Response Time dimension 3.269, and the lowest value in the Ease of Use dimension generating an index of 2.986. This shows that in terms of users, the overall quality of the system is perceived to be adequate with the advantages of a system that responds quickly to instructions given by users who require attention in terms of access. This certainly can minimize interference for user convenience (Tabel 5).

Tabel 5. The respondent's answer index for the system quality variable

\begin{tabular}{llc}
\hline Indicator & Index & Category \\
\hline Flexible to make changes as required & 3,214 & adequate \\
\hline $\begin{array}{l}\text { Integrated with other features and menus that are related either directly or } \\
\text { indirectly }\end{array}$ & 2,986 & adequate \\
\hline $\begin{array}{l}\text { Can be accessed smoothly by minimizing distractions to provide convenience in } \\
\text { use }\end{array}$ & 3,106 & Adequate \\
\hline \begin{tabular}{l} 
Responds quickly to orders given by users \\
$\begin{array}{l}\text { The language used is standard and easy to understand, the system can be used } \\
\text { with appropriate instructions }\end{array}$ \\
\hline
\end{tabular} & 3,269 & Adequate \\
\hline
\end{tabular}

Source: primary data processed

The respondent's answer index for the information quality variable is 3,236 . All indicators were categorized as sufficient with the highest value in the Completeness dimension generating an index of 3,340 and the lowest value in the Relevant dimension obtaining 3,154 indexes. This affirms that from the user's point of view, the overall quality of information is considered adequate with the advantages of the system in providing complete information. It still requires attention in terms of ensuring data security (Tabel 6). 
Tabel 6. The respondent's answer index for the information quality variable

\begin{tabular}{lll}
\hline Indicator & Index & Category \\
\hline Provide complete information & 3,340 & adequate \\
\hline The format is adequately clear and comprehensive & 3,254 & adequate \\
\hline Provides up-to-date information & 3,266 & adequate \\
\hline Provide guaranteed data security & 3,154 & adequate \\
\hline Provide accurate and precise information & 3,166 & adequate \\
\hline Source: primary data processed & &
\end{tabular}

The respondent's answer index for the service quality variable was 3.249. All indicators were categorized as sufficient with the highest score in the Understanding dimension which obtained 3,320 and the lowest value found on the Availability dimension which generated
3,160 . This shows that according to users, the overall quality of service is perceived to be adequate with the advantage of being able to help complete tasks more quickly, and it still requires attention in terms of convenience for users (Tabel 7).

Tabel 7. The respondent's answer index for the service quality variable

\begin{tabular}{lcc}
\hline Indicator & Index & Category \\
\hline Make it easy for users & 3,160 & adequate \\
\hline Information obtained is reliable & 3,166 & adequate \\
\hline There are ways to convey obstacles or find solutions to the problems at hand & 3,306 & adequate \\
\hline $\begin{array}{l}\text { Provide socialization and education regarding clear instructions for use and } \\
\text { updates }\end{array}$ & 3,294 & adequate \\
\hline Help complete tasks faster & 3,320 & adequate \\
\hline
\end{tabular}

Source: primary data processed

The response index for user generating 3,137. This shows that in terms satisfaction variables was 3,223 , all of users, overall user satisfaction is indicators were categorized as sufficient perceived to be sufficient with the with the highest value in the System advantage of being able to meet the desired Effectiveness dimension, which accounted goals although it requires attention in for 3,300 and the lowest value on the terms of meeting expected needs (Tabel 8). System Fit for Need dimension, which only

Tabel 8. The respondent's answer index for the user satisfaction variable

\begin{tabular}{llc}
\hline Indicator & Index & Category \\
\hline Meet the expected needs & 3,137 & adequate \\
\hline Fulfill the desired objectives & 3,300 & adequate \\
\hline Supporting time efficiency and use of resources & 3,249 & adequate \\
\hline $\begin{array}{l}\text { Satisfaction in using the system due to the good quality of the system, } \\
\text { information, and services in general. }\end{array}$ & \multirow{2}{*}{3,206} & adequate \\
\hline Source: primary data processe &
\end{tabular}

Source: primary data processed

The respondent's answer index for the net benefits received by individuals and organizations was 3,211. All indicators were categorized as sufficient with the highest value on the Usefulness dimension generating 3.269 and the lowest value on the Effectiveness dimension obtaining
3.197. This shows that in terms of users, the net benefits received by individuals and organizations are perceived to be sufficient with the advantage of being useful for users in supporting individual and organizational performance, but it still 
requires attention in terms of efficiency of the system use (Tabel 9).

Tabel 9. The respondent's answer index for the net benefit variable

\begin{tabular}{lcc}
\hline Indicator & Index & Category \\
\hline $\begin{array}{l}\text { The use of the system is useful in supporting the performance of individuals and } \\
\text { companies }\end{array}$ & 3,269 & adequate \\
\hline $\begin{array}{l}\text { The use of the system is useful in supporting the productivity of individuals and } \\
\text { companies. }\end{array}$ & 3,174 & adequate \\
\hline The use of the system increases the effectiveness of individuals and companies & 3,206 & adequate \\
\hline The use of the system meets the efficiency of individuals and companies. & 3,197 & adequate \\
\hline
\end{tabular}

Source: primary data processed

Based on primary data processed with CB-SEM, each indicator has its p-value, chi-square, Skewness, and Kurtosis greater than 0.05. Univariately, data normality and multivariate normality had been fulfilled. The correlation value between the independent variables was lower than 0.8. Therefore, it could be concluded that there was no multicollinearity model.

Each indicator had an SLF value greater than 0.5 , meaning that all of these indicators were declared valid. Each variable also had an AVE value greater than 0.5 . Therefore, it could also be stated that each variable had a good convergent and discriminant validity (Tabel 10).

Tabel 10. Convergent and discriminant validity

\begin{tabular}{|c|c|c|c|c|}
\hline Variable & Indicator & $\lambda$-SLF & AVE & Status \\
\hline \multirow{5}{*}{$\begin{array}{l}\text { X1 } \\
\text { System Quality }\end{array}$} & X1.1 & 0.737 & \multirow{5}{*}{0.503} & \multirow{5}{*}{ Valid } \\
\hline & $\mathrm{X} 1.2$ & 0.769 & & \\
\hline & $\mathrm{X} 1.3$ & 0.641 & & \\
\hline & X1.4 & 0.747 & & \\
\hline & $\mathrm{X} 1.5$ & 0.640 & & \\
\hline \multirow{5}{*}{$\begin{array}{l}\text { X2 } \\
\text { Information Quality }\end{array}$} & X2.1 & 0.706 & \multirow{5}{*}{0.500} & \multirow{5}{*}{ Valid } \\
\hline & $\mathrm{X} 2.2$ & 0.683 & & \\
\hline & $\mathrm{X} 2.3$ & 0.685 & & \\
\hline & $\mathrm{X} 2.4$ & 0.720 & & \\
\hline & $\mathrm{X} 2.5$ & 0.738 & & \\
\hline \multirow{5}{*}{$\begin{array}{l}\text { X3 } \\
\text { Service Quality }\end{array}$} & X3.1 & 0.778 & \multirow{5}{*}{0.513} & \multirow{5}{*}{ Valid } \\
\hline & X3.2 & 0.658 & & \\
\hline & X3.3 & 0.631 & & \\
\hline & X3.4 & 0.808 & & \\
\hline & X3.5 & 0.690 & & \\
\hline \multirow{4}{*}{$\begin{array}{l}\text { Z } \\
\text { User Satisfaction }\end{array}$} & $\mathrm{Z1}$ & 0.758 & \multirow{4}{*}{0.513} & \multirow{4}{*}{ Valid } \\
\hline & $\mathrm{Z} 2$ & 0.664 & & \\
\hline & $\mathrm{Z3}$ & 0.657 & & \\
\hline & $\mathrm{Z4}$ & 0.779 & & \\
\hline \multirow{4}{*}{$\begin{array}{l}\text { Y } \\
\text { Net Benefit }\end{array}$} & Y1 & 0.794 & \multirow{4}{*}{0.501} & \multirow{4}{*}{ Valid } \\
\hline & Y2 & 0.635 & & \\
\hline & Y3 & 0.666 & & \\
\hline & Y4 & 0.727 & & \\
\hline
\end{tabular}

Source: primary data processed

Each variable has a Composite variables meet the reliability value (Tabel Reliability (CR) value greater than 0.7. 11).

Therefore, it can be concluded that all 
Tabel 11. Composite Reliability

\begin{tabular}{lll}
\hline Variable & Composite Reliability (CR) & Conclusion \\
\hline System Quality & 0.834 & Reliable \\
\hline Information Quality & 0.833 & Reliable \\
\hline Service Quality & 0.839 & Reliable \\
\hline User Satisfaction & 0.800 & Reliable \\
\hline Net Benefit & 0.808 & Reliable \\
\hline Source: primary data processed &
\end{tabular}

The structural measurement effort of the full model has resulted in an acceptable goodness of fit. Thus, the full fit or significant structural model can be employed in the research hypothesis testing stage (Tabel 12 and 13).

Tabel 12. Goodness of fit index

\begin{tabular}{llll}
\hline Goodness of fit index & Cut-off value & Results of Study & Conclusion \\
\hline $\mathrm{X}^{2}$ & $<\mathrm{X}^{2}$ tabel & 215,34 & Good fit \\
\hline $\mathrm{df}=$ & 223 & & \\
\hline $\mathrm{X}^{2}$ tabel $=$ & 258,837 & & \\
\hline RMSEA & $\leq 0,08$ & 0,00 & Good fit \\
\hline GFI & $\geq 0,90$ & 0,95 & Good fit \\
\hline AGFI & $\geq 0,90$ & 0,94 & Good fit \\
\hline IFI & $\geq 0,90$ & 1,00 & Good fit \\
\hline CFI & $\geq 0,90$ & 1,00 & Good fit \\
\hline NFI & $\geq 0,90$ & 0,96 & Good fit \\
\hline NNFI & $\geq 0,90$ & 1,00 & Good fit \\
\hline RFI & $\geq 0,90$ & 0,95 & Good fit \\
\hline
\end{tabular}

Source: primary data processed

Tabel 13. Structural Equation

\begin{tabular}{llll}
\hline Equation & Equation & Path Coefficient & t-statistic \\
\hline \multirow{4}{*}{ System Quality } & 0.16 & 2.43 \\
& Information Quality & 0.20 & 2.95 \\
2 & Service Quality & 0.26 & 4.08 \\
& Net Benefit & 0.64 & 9.28 \\
\hline \multicolumn{2}{l}{ Equation } & R-square & \\
\hline 1 & 0.17 & \\
\hline \multicolumn{2}{l}{ Source: primary data processed }
\end{tabular}

First Hypothesis. H1: The has a positive and significant effect on user information system quality has a positive satisfaction of the e-Filing system. The effect on user satisfaction with the e-Filing value of the direct effect of the system system

The results of the hypothesis testing concerning the relationship of information system quality against user satisfaction generated a significance level of $\alpha$ of 0.05 , the t-statistical value of $2.43>$ t-table 1.96 , indicating that the hypothesis was accepted. The results of this test indicate that the quality of the information system quality on user satisfaction was 16 percent.

The second hypothesis. $\mathrm{H} 2$ : Information quality has a positive effect on user satisfaction of the e-Filing system

The results of hypothesis testing regarding the relationship of information quality to user satisfaction generated a significance level of $\alpha$ of 0.05 , t-statistical value of 2.95> t-table 1.96, indicating that 
the hypothesis is accepted. The results of this test indicate that the quality of information has a positive and significant effect on user satisfaction of the e-Filing system. The value of the direct effect of information quality on user satisfaction is 20 percent.

The third hypothesis. H3: The quality of service has a positive effect on user satisfaction with the e-Filing system

The results of hypothesis testing regarding the relationship of service quality to user satisfaction generated a significance level of 0.05 , the t-statistical value of 4.08> t-table 1.96, indicating that the hypothesis was accepted. The results of this test indicate that service quality has a positive and significant effect on user satisfaction with the e-Filing system. The value of the direct effect of service quality on user satisfaction was 26 percent.

The fourth hypothesis. H4: User satisfaction on the e-Filing system has a positive effect on net benefits for individuals and organizations

The results of hypothesis testing regarding the relationship between user satisfaction and net benefits for individuals and organizations generated a significance level $\alpha$ of 0.05 , t-statistic value 9.28> ttable 1.96, indicating that the hypothesis is accepted. The results of this test indicate that user satisfaction on the e-Filing system has a positive and significant effect on net benefits for individuals and organizations. The value of the direct effect of user satisfaction on the net benefits for individuals and organizations was 64 percent.

\section{CONCLUSION}

The information system quality has a positive and significant effect on user satisfaction using the e-Filing system at the Palembang Ilir Barat Pratama Tax Office. The magnitude value of the direct effect of system quality on user satisfaction amounted to 16 percent. The strong influence of system quality is due to the five indicators of the dimensions. These indicators are ordered sequentially from the most influential: integration, response time, flexibility, ease of use, and language.

The information quality has a positive and significant effect on user satisfaction using the e-Filing system at the Palembang Ilir Barat Pratama Tax Office. The magnitude value of the direct effect of information quality on user satisfaction amounted to 20 percent. The strong influence of information quality is due to the five indicators of the dimensions. These indicators are ordered sequentially from the most influential: accuracy, security, completeness, easy to understand, and relevance.

Service quality has a positive and significant effect on user satisfaction using the e-Filing system at the Palembang Ilir Barat Pratama Tax Office. The magnitude value of the direct effect of information quality on user satisfaction amounted to 26 percent. The strong influence of service quality is due to the five indicators of the dimensions. These indicators are ordered sequentially from the most influential: the ability to convince, availability, understanding, reliability, and responsiveness to constraints.

User satisfaction on the e-Filing system has a positive and significant effect on net benefits for individuals and organizations at the Palembang Ilir Barat Pratama Tax Office. The magnitude value of the direct effect of user satisfaction on the net benefits for individuals and organizations amounted to 64 percent. The strong influence of user satisfaction is due to four indicators from the dimensions of which are ordered from the most influential: overall satisfaction, a system that meets needs, system effectiveness, and system efficiency. Meanwhile, the net benefit is also influenced by two indicators from the dimensions of which are ordered from the most influential: benefit and effectiveness. 
It can be concluded that DeLone and McLean's success model concerning information systems which has been updated (2003) is proven empirically in the implementation of the e-Filing system against corporate taxpayers at the Palembang Ilir Barat Pratama Tax Office. The implementation of this policy can be optimal if every dimension in system quality, information quality, and service quality provided can increase user satisfaction. Therefore, users can get maximum net benefits.

Although it is mandatory, it turns out that the e-Filing system which has been implemented can provide satisfaction to system users. This means that the existing system is currently in the expected condition. The mandatory nature is not only the main cause of system reuse but also the comfort and satisfied feeling perceived by users towards the system. However, the output of the services provided in the form of taxpayer compliance has not shown optimal results.

\section{BIBLIOGRAPHY}

Amriani, T. N., \& Iskandar, A. (2019). Analisis Kesuksesan Implementasi Sistem Aplikasi Keuangan Tingkat Instansi (SAKTI) pada Satuan Kerja di Lingkungan Badan Pendidikan dan Pelatihan Keuangan (BPPK). Kajian Ekonomi Dan Keuangan, 3(1), 54-74. https://doi.org/https://doi.org/10.31685/k ek.v3i1.409

Bahesa, B. P. (2018). TA : Analisis Kesuksesan Sistem Informasi Website Pemerintah Kabupaten Pamekasan Berdasarkan Model Delone and Mclean.

Choi, H., Park, M. J., Rho, J. J., \& Zo, H. (2016). Rethinking the assessment of e-government implementation in developing countries from the perspective of the design-reality gap: Applications in the Indonesian eprocurement system. Science Direct, 40(7), 644-660.

https://doi.org/10.1016/j.telpol.2016.03.00 2

Christanti, R. (2015). Model Kesuksesan Sistem Pelaporan Pajak Penghasilan Berbasis Elektronik: Studi Pada Perilaku Wajib Pajak Badan Atas Penggunaan Aplikasi-Aplikasi Pelaporan Spt Tahunan. Pengaruh Harga Diskon Dan Persepsi Produk Terhadap Nilai
Belanja Serta Perilaku Pembelian Konsumen, 7(9), 27-44.

Christanti, R. (2019). Model Kesuksesan Sistem Pelaporan Pajak Penghasilan Berbasis Elektronik: Studi Pada Perilaku Wajib Pajak Badan. journal.ugm.ac.id. https://journal.ugm.ac.id/abis/article/view /58836

Hidayat, S. N. (2019). Analisis Perbandingan Keberhasilan dan Penerimaan Lima ECommerce Di Indonesia menggunakan Model Delone \& Mclean yang di kembangkan. In Journal of Chemical Information and Modeling (Vol. 53, Issue 9). http://repository.uinjkt.ac.id/dspace/handl e/123456789/48530

Ihsan, M. A. A. (2018). Analisis Faktor-Faktor Yang Mempengaruhi Kesuksesan Implementasi Sistem E-Filing Pajak: Studi Kasus Kantor Pelayanan Pajak Madya Makassar. Jurnal BPPK, 11(1), 12-34.

Irfan, M. (2019). Pengaruh Kualitas Sistem, Kualitas Informasi, Dan Kualitas Pelayanan Terhadap Net Benefits Pemakaian Sistem Pembayaran Briva.

https://dspace.uii.ac.id/handle/123456789 $/ 14158$

Iskandar, A, (2016). Evaluation of Accrual Basic Application System (SAIBA) Impelementation on The KPPN Gorontalo and Marisa's Steakholders. Jurnal Tata Kelola \& Akuntabilitas Keuangan Negara, 2(Desember), 111-135.

Mardiana, S., Tjakraatmadja, J. H., \& Aprianingsih, A. (2015a). DeLone-McLean Information System Success Model Revisited: The Separation of Intention to Use -Use and the Integration of Technology Acceptance Models. International Journal of Economics and Financial Issues, 5(5), 172-182.

Mardiana, S., Tjakraatmadja, J. H., \& Aprianingsih, A. (2015b). Validating the Conceptual Model for Predicting Intention to Use as Part of Information System Success Model: The Case of an Indonesian Government Agency. Procedia Computer Science, 72, 353-360. https://doi.org/10.1016/j.procs.2015.12.15 0

Muttaqin, A. (2020). Analisis Dimensi Kesuksesan Layanan Hai Djpb Dengan Pendekatan Model Delone Dan Mclean (Studi Kasus Satker Lingkup Kanwil DJPB bahan tesis. Jimfeb.Ub.Ac.Id.

https://jimfeb.ub.ac.id/index.php/jimfeb/ar ticle/view/6275

Puspita, P. S., \& Ritchi, H. (2017). Deduksi model kesuksesan sistem informasi Delone and Mclean pada implementasi di lingkungan pemerintah 
https://repository.widyatama.ac.id/xmlui/h andle/123456789/8608

Santhanamery, T., \& Ramayah, T. (2012). Continued Usage Intention of E-Filing System in Malaysia: The Role of Optimism Bias. 65(ICIBSoS), 397-403. https://doi.org/10.1016/j.sbspro.2012.11.1 40

Santhanamery, T., Ramayah, T., Akuntan, P., Sustainable, M., Practice, B., Olaoye, C. O., Kehinde Busayo, A., Amriani $\alpha$, T. N. dan A. I., Maiti, Bidinger, Christanti, R., Irfan, M. M., Bea, J., Cukai, D. A. N., Mubiroh, S., Wardana, A. K., Pajak, E. W., Pribadi, O., 野田育宏, ...

Siregar, K. (2015). Pengaruh Implementasi Kebijakan Terhadap Kualitas Pelayanan Swasembada Beras Di Kabupaten Simeulue.

Surdin, J., \& Ilmu. (2016). Analisis Kelayakan Implementasi E-Government Dalam Pelayanan Publik Di Bidang Keagrariaan Di Kabupaten Pinrang. Komunikasi KAREBA, 5(1), 178-191.
Tjahjadi, Y. E. R. O. (2014). Analisis Penerimaan EFiling Pada Wajib Pajak. Accounting and Business Information Systems Journal, 1(3).

Wahyuni, T. (2011). Uji Empiris Model Delone Dan Mclean Terhadap Kesuksesan Sistem Informasi Manajemen Daerah (SIMDA). Jurnal BPPK, 2, 4-24.

Wahyuni, T. (2019). Model Kesuksesan Sistem Pelaporan Pajak Penghasilan Berbasis Elektronik: Studi Pada Perilaku Wajib Pajak Badan Atas Penggunaan Aplikasi-Aplikasi Pelaporan Spt Tahunan. Pengaruh Harga Diskon Dan Persepsi Produk Terhadap Nilai Belanja Serta Perilaku Pembelian Konsumen, 53(9), 27-44. https://doi.org/10.1016/j.sbspro.2012.11.1 40

Wibisono, L. T., \& Toly, A. A. (2014). Analisis FaktorFaktor Yang Mempengaruhi Minat Wajib Pajak Dalam Penggunaan E-Filing Di Surabaya. Tax \& Accounting Review, 4(1), 115. 